\title{
FOXTAIL MUHLY NEW TO SASKATCHEWAN, RIGID SEDGE REAFFIRMED, ADDITIONAL RANGE EXTENSIONS
}

JOHN H. HUDSON, 103 Richmond Crescent, Saskatoon, Saskatchewan. S7K 1A9

During a sojourn in August 1985 at Camp Okema, the Anglican church camp at Emma Lake, I had the good fortune to find a grass not hitherto reported for Saskatchewan. It is Foxtail Muhly [Muhlenbergia andina (Nutt.) Hitchc.]. In general aspect it looks something like Marsh Muhly [Muhlenbergia racemosa (Michx.) B.S.P.], except that the single terminal head is a bit denser and definitely furry-looking. A good key will be found in Budd's Flora wherein it is pointed out that Foxtail Muhly has an awned lemma and more or less awnless glumes, while Marsh Muhly has awned glumes and an awnless lemma. ${ }^{4}$ In Foxtail Muhly the lemma is furnished with basal hairs so long that they exceed the lemma and cause the furry look of the inflorescence.

Collection data are: \#4570, 26 August 1985, damp, limy, gravelly beach of Emma Lake, south shore of peninsula 0.75 mi. west of Okema Beach, sw. corner L.S.D. 6 in $29-53-27-W 2\left(53^{\circ} 36^{\prime} \mathrm{N} 105^{\circ}\right.$ $\left.57^{\prime} \mathrm{W}\right)$.

The range and habitat are the remarkable things about this species. As to the range, Looman reported collecting this grass at Birch River Community Pasture and at Laurie Lake, Duck Mountain Provincial Park, both in Manitoba. ${ }^{8}$ He noted with puzzlement the wide separation of these places from the plant's main range in the western mountains of the United States. Scoggan did not mention this one at all, even for B.C. ${ }^{9}$ Boivin mentioned an older collection from Clear
Lake, Riding Mountain National Park. ${ }^{2}$ The collection reported here goes a little way to bridging the disjunction noted by Looman.

Boivin gave the habitat, likely from a label, as "gravelly shores." Looman stated his Birch River collection was from a "wet area in shallow depression", his Laurie Lake one "on moist rocky beach", and both were "somewhat saline wet soil." Plainly these areas are seepage of limebearing groundwater to surface which would be expected to occur here and there along the shores of lakes on limy glacial drift. The beach of Emma Lake on the Camp Okema property presents a long strip of the vegetation of calcareous groundwater bogs without any truly boggy soil. This strip is between the lowest old beach and the water; presumably the fall of lake level in historic times gives a little more gradient for the groundwater to seep to the surface. There appears to be no moss or peat on the strip; maybe the fall in lake level has been too recent (within 50 or 60 years) for a peaty layer to form. The resultant vegetation is a joy to the eye: I wrote down in my notes seeing blue Kalm's Lobelia, white Rush Aster, Asphodel with its red capsules, and Carex viridula [Greenish Sedge] contributing a touch of yellow-green, all in the same square foot.

In "Carex in Saskatchewan" there were entries under the names Carex meadii Dewey and Carex tetanica Schkuhr. ${ }^{6}$ These names might or might not be con- 
specific; Boivin thought so -1 really could not hold an opinion one way or the other for want of evidence. ${ }^{1}$ These had been collected in the early days by Macoun, as follows: $C$. meadii as Macoun \#31475. File Hills, 4 July 1879 , and Macoun and Herriot \#72692, base of Spy Hill 1 July 1906, both checked by K.K. Mackenzie; C. tetanica as Macoun and Herriot \#72773, 2 July 1906, at Redpath, 8-10 mi. nw of Spy Hill. These are in the National Museum of Canada; I have seen the two 1906 specimens on loan. Since the habitat was given as moist prairie, and since the two species had not been collected in Saskatchewan for 70 years, I suggested that the species was/were extinct in the province due to the depredations of farming and the inroads of brome grass.

I am pleased to report that this suggestion was wrong. The first news that Rigid Sedge was still with us came in a letter from P.W. Ball of the University of Toronto, saying that he had seen $C$. tetanica as the collection Boivin and Dore 7822 from Kisbey in 1951, mislabelled as Carex aurea [Golden Sedge]. There chanced to be another replicate of this collection in the Fraser Herbarium, so I could check this for myself. Now knowing that $C$. tetanica did not look like $C$. crawei [Crawe's Sedge] or C. livida [Pale leadcolored Sedge] as I had surmised, but very much like $C$. aurea, I looked over my own collections, and found a specimen of $C$. tetanica, \#3599, from Saltcoats, 21 July 1978, which I had taken to be a diseased or blighted $C$. aurea. This showed the habitat of $C$. tetanica to be marly groundwater-fed meadows, of the sort where Mealy Primrose or White Camas are found.

Live Carex tetanica was located on Strawberry Lake north of Odessa with George Ledingham - the collection was Ledingham and Hudson 4616, 22 June 1986 , moist shrubby calcareous groundwater meadow, L.S.D. 9 in 20-16-13-W2 $\left(50^{\circ} 22^{\prime} \mathrm{N} 103^{\circ} 46^{\prime} \mathrm{W}\right)$. This material was young and slender but the three stigmas on the perigynia distinguished it from Carex aurea which it at first appeared to be.

Later in the summer a visit was made to a series of ground water bogs between Carievale and Carnduff, 1-2 mi. south of Highway 18 , whose existence I had inferred from the 1:50,000 topographic map. There the following collections of $C$. tetanica were made: \#4651, 2 August 1986, wet, hummocky, marly groundwater bog, L.S.D. 8 in 28-2-32-W1 (490 $\left.10^{\prime} \mathrm{N} 101^{\circ} 44^{\prime} \mathrm{W}\right) ; \# 4654$, same date and land number, down in a wetter flatter bog with Baltic Rush and Northern Reed Grass [Calamagrostis inexpansa]; \#4660, same date, moist groundwater-fed meadow, L.S.D. 15 in $28-2-32-\mathrm{W} 1\left(49^{\circ} 10^{\prime} \mathrm{N} 101^{\circ}\right.$ $44^{\prime} \mathrm{W}$ ). Numbers 4654 and 4660 are tallish plants 3 or $4 \mathrm{dm}$ high with pistillate spikes 3-5 mm thick, which would never be confused with Carex aurea in life; but the pistillate spikes are not the $5-7 \mathrm{~mm}$ wide that authors of Eastern floras, like Fernald specify for $C$. meadii. ${ }^{5}$ t therefore tentatively conclude that Boivin was correct in writing that $C$. meadii is conspecific with $C$. tetanica, at least for Canadian material. ${ }^{1}$ It must be remembered, however, that four sheets from the edge of the range are not a good sample of a whole population.

There have been a few more range extensions and verifications of old collections to report from the seasons of 1984, 1985, and 1986.

A.J. Breitung reported Twig-Rush [Cladium mariscoides Torr.] from Dahlton and McKague. ${ }^{3}$ Boivin used label data to give the locality as Wallwort near Dahlton. ${ }^{1}$ All these localities refer to the same bog. Twig-Rush has not turned up elsewhere in Saskatchewan in the 50 years since the Breitung collections were made in 1936 and 1937. Its main range starts 


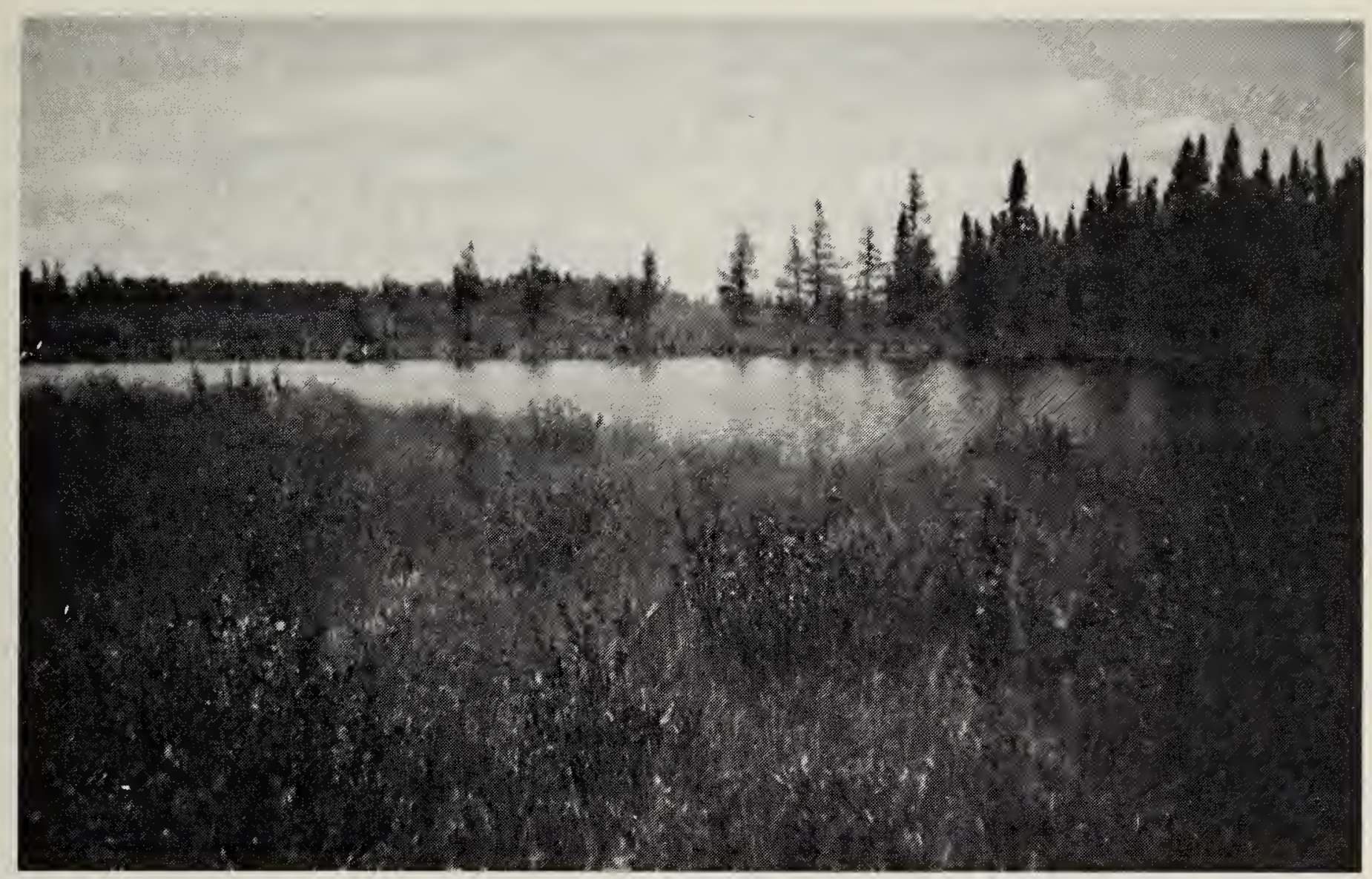

Twig-Rush colony at left on shore of pond

J.H. Hudson

at Batachawana Bay, eastern Lake Superior, according to Scoggan, and goes east from there. ${ }^{9}$ Breitung in letters to me wondered whether this isolated station still existed, and asked me to revisit the site, indicating on maps where the bog lay. I went up for a weekend and found the bog. My difficulties and adventures in looking for it occupy 3.5 pages in my journal but need not be set forth here other than to say I ended the first day's search by getting most thoroughly lost. On the Sunday I was more successful and found the bog and Twig-Rush as \#4660, 8 July 1984 , wet spots in bog west of central lakelet, L.S.D. 15 in $17-41-15-W 2\left(52^{\circ}\right.$ $\left.32^{\prime} \mathrm{N} 104^{\circ} 08^{\prime} \mathrm{W}\right)$.

\section{A couple of range extensions are:}

Granular Sedge [Carex granularis Muhl] \#4594, 14 September 1985, on cow trail at foot of slope just above marsh, $n$ side Shell River valley, s edge L.S.D. 10 in 35-49-4-W3 (53 $\left.16^{\prime} \mathrm{N} 106^{\circ} \quad 28^{\prime} \mathrm{W}\right)$, Shellbrook area. This is further northwest yet from a Rosthern report. ${ }^{7}$
Flowering Quillwort [Lilaea scilloides (Pair.) Haum] \#4520, 6 July 1985. Field pothole (cultivated small slough that the farmer could not sow in spring because it was too wet), still wet, in sandy loam soil, w edge L.S.D. 4 in 2-33-10-W3 (510 $48^{\prime} \mathrm{N} 107^{\circ} 20^{\prime} \mathrm{W}$ ), near Laura. Reported by Boivin in Saskatchewan from Trossachs, Spring Valley, and (former post office) Belanger. ${ }^{1}$ Are some of these field pothole oddities spread by farm machinery now?

Duplicates of the 1985 and 1986 collections have been distributed to the herbaria of the University of Saskatchewan, of the University of Regina, and of the National Museum of Canada; of the 1984 collection to the two former ones.

1 BOIVIN, B. 1979. Flora of the Prairie Provinces. Part IV. Provancheria \#5. Universite Laval, Quebec City.

2 BOIVIN, B. 1981. Flora of the Prairie Provinces. Part V. Provancheria \#12. Universite Laval, Quebec City. 
3 BREITUNG, A.J. 1947. Catalogue of the Vascular Plants of Central Eastern Saskatchewan. The Canadian Field-Naturalist 61 (3):71-700.

4 BUDD, A.C. 1979. Flora of the Canadian Prairie Provinces. Revised and enlarged by J. Looman and K.F. Best. Research Branch Agriculture Canada Publication 1662.

5 FERNALD, M.L. 1950. Gray's Manual of Botany. 8th edition. American Book Co. New York.
6 HUDSON, J.H. 1977 Carex in Saskatchewan. Bison Publishing House, Saskatoon.

7 HUDSON, J.H. 1984. A Second Evening Star in Saskatchewan. Blue Jay 42(1):21.

8 LOOMAN, J. 1973. Some New and Interesting Plant Records for the Prairie Provinces. Blue Jay 31(3):176-179.

9 SCOGGAN, H.J. 1978. Flora of Canada. Part 2. National Museums of Canada. Ottawa.

\section{WILDLIFE HABITAT RECLAMATION MANUAL}

A manual for reclamation of wildlife habitat is now available from Environment Canada Western and Northern Region. The manual was prepared for Environment Canada and the Alberta Recreation, Parks and Wildlife Foundation by the Delta Environmental Management Group Ltd. of Calgary while Wildlife Habitat Canada funded its printing.

The manual describes concepts and techniques applicable to major biomes in the Canadian prairie provinces. Included are the Mountains and Foothills, Boreal Forest, Aspen Parkland and Prairie Grasslands.

Until recently, reclamation goals in western Canada traditionally adopted either forestry or agriculture as end uses for reclaimed lands, depending on the particular location and landform. However, with improved reclamation methods and an increased awareness of the value of natural areas, greater emphasis has been placed on reclamation and enhancement of wildlife habitat.

This manual is a concise summary of state of the art knowledge gleaned from numerous industrial operators actively involved in land reclamation programs and from extensive scientific literature dealing with wildlife habitat management. It introduces wildlife habitat reclamation concepts, provides direction on preparing a reclamation plan and includes timing and resource considerations. In addition, details for modifying landforms, developing water bodies and establishing plant commurities suitable for key wildlife species are presented.

Copies of the manual were made available from the following address: Communications Branch, Environment Canada, Western and Northern Region, Twin Atria 2, 2nd Floor, 4999 - 98 Avenue, Edmonton, Alberta. T6B 2X3 